\title{
Combination of Vorinostat with Whole-brain Radiotherapy in the Treatment of Brain Metastases
}

\author{
Y. R. Lawrence \\ Thomas Jefferson University and Hospitals \\ R. M. Pfeffer \\ Chaim Sheba Medical Center \\ M. Werner-Wasik \\ Thomas Jefferson University and Hospital \\ H. Choy \\ University of Texas Southwestern Medical Center
}

A. Dicker

Thomas Jefferson University and Hospitals.

Follow this and additional works at: https://jdc.jefferson.edu/bodinejournal

Part of the Oncology Commons

Let us know how access to this document benefits you

\section{Recommended Citation}

Lawrence, Y. R.; Pfeffer, R. M.; Werner-Wasik, M.; Choy, H.; and Dicker, A. (2010) "Combination of Vorinostat with Whole-brain Radiotherapy in the Treatment of Brain Metastases," Bodine Journal: Vol. 3 : Iss. 1 , Article 7.

DOI: https://doi.org/10.29046/TBJ.003.1.006

Available at: https://jdc.jefferson.edu/bodinejournal/vol3/iss1/7

This Article is brought to you for free and open access by the Jefferson Digital Commons. The Jefferson Digital Commons is a service of Thomas Jefferson University's Center for Teaching and Learning (CTL). The Commons is a showcase for Jefferson books and journals, peer-reviewed scholarly publications, unique historical collections from the University archives, and teaching tools. The Jefferson Digital Commons allows researchers and interested readers anywhere in the world to learn about and keep up to date with Jefferson scholarship. This article has been accepted for inclusion in Bodine Journal by an authorized administrator of the Jefferson Digital Commons. For more information, please contact: JeffersonDigitalCommons@jefferson.edu. 


\title{
Combination of Vorinostat with Whole-brain Radiotherapy in the Treatment of Brain Metastases
}

\author{
Lawrence, Y.R., ${ }^{1}$ Pfeffer, R.M., ${ }^{2}$ Werner-Wasik, M., ${ }^{1}$ Choy, H., ${ }^{3}$ Dicker, A. ${ }^{1}$ \\ ${ }^{1}$ Department of Radiation Oncology, Thomas Jefferson University and Hospitals, Philadelphia, PA \\ ${ }^{2}$ Chaim Sheba Medical Center, Tel Aviv, Israel \\ 3University of Texas Southwestern Medical Center, Dallas, TX
}

\section{Background}

A third of patients with solid malignancies develop brain metastases. Expected overall survival is 4-7 months depending on age, performance status, and extracranial disease. Standard treatment is controversial; however, the majority of patients receive wholebrain radiation therapy at some point. Vorinostat (suberoylanilide hydroxamic acid, SAHA), an FDA-approved HDAC inhibitor, has been demonstrated to radiosensitize tumor cells in vitro, as assessed by both radiation-induced DNA damage and clonogenic cell survival (Munshi et al. Molecular Cancer Therapeutics 5, 1967-1974, 2006). We have shown that vorinostat downregulates key genes involved in double-strand DNA repair (Rad50, Rad51, XRCC2, XRCC3, XRCC6), as assessed by quantitative PCR. This suggests that the drug's mechanism of radiosensitization is epigenetic coordinated inhibition of the DNA repair process. We hypothesize that the combination of vorinostat with whole-brain radiation therapy will be both safe and efficacious.

\section{Methods}

This is a dose escalation phase I investigational trial, based on Fibonacci $3+3$ design. Whole-brain radiation is delivered in daily fractions of 2.5 Gy over 3 weeks (total dose 37.5 Gy) delivered through parallel opposed fields. Vorinostat is delivered once daily on days of radiation therapy. Dose levels: increase from $200 \mathrm{mg}$ PO qd to $400 \mathrm{mg}$ PO qd in subsequent patient cohorts, with an option de-escalate if $200 \mathrm{mg}$ is found overly toxic. Expected total accrual: 9-18 patients. Primary endpoint is tolerability; secondary endpoint is overall survival. Open to accrual at Thomas Jefferson University, Philadelphia PA; UT Southwestern Medical Center, Dallas, TX and Sheba Medical Center, Tel Aviv, Israel.

Studyissupported by Merck. ClinicalTrials.govIdentifier:NCT00838929. 